\title{
IMAGENS E PERFORMANCES DE CRIANÇAS NO NÊGO FUGIDO EM ACUPE/BA
}

\author{
Maria José Villares Barral Villas Boas ${ }^{1}$
}

Em Acupe, distrito do munícipio de Santo Amaro, no Recôncavo Baiano, existem várias manifestações tradicionais sazonais. Em julho, durante à tarde de todos os domingos emerge o Nêgo Fugido. A manifestação é uma expressão artística da cultura popular de caráter polissêmico. Os habitantes da localidade, população majoritariamente negra, descendentes quilombolas, que mantém a pesca e a mariscagem como principal atividade econômica, descrevem o Nêgo Fugido como folclore, cultura popular, etc. Neste artigo, tomo como base a minha monografia de graduação e a dissertação de mestrado (Villas Boas, 2013; 2016) para reflexão sobre a performance e o agenciamento das crianças na manifestação e frente a câmera fotográfica ${ }^{2}$. Tendo isso como propósito, exploro as imagens e o imaginário dessas crianças participantes. Proponho trazer para o debate questões sobre a construção compartilhada da imagem de si e do imaginário sobre classe e raça dos sujeitos a partir das discriminações experimentadas por elas cotidianamente, especialmente por conta do racismo. Tais experiências são expressadas performaticamente cotidianamente e na manifestação popular. $\mathrm{O}$ artigo também tenta compreender como se dá a construção de saber sensorial e da constituição de si de crianças negras no Recôncavo Baiano que manifestam esse conhecimento no Nêgo Fugido.

O Nêgo Fugido leva às ruas a encenação de alguns elementos integrantes da vida do escravo do Recôncavo Baiano que detinha um comportamento muito específico: fugia de seu senhor para divertir-se ${ }^{3}$. De rostos pintados de óleo e carvão ${ }^{4}$, boca

\footnotetext{
${ }^{1}$ Universidade de Brasília, Brasil.

2 Agradeço a toda comunidade de Acupe, em especial à Associação Cultural Nêgo Fugido, pela disponibilidade contínua em participar da pesquisa. Minha gratidão também à Profa. Dra. Fabiene Gama, e às colegas participantes do grupo de estudos Núcleo de Antropologia Sensorial do Departamento de Antropologia da Universidade de Brasília (NuAS) pelo contribuição para o desenvolvimento deste trabalho.

${ }^{3}$ Ana Maria Ramos explica que, no contexto histórico registrado sobre a resistência negra no Brasil escravista, no primeiro momento, a conquista pela liberdade é dada pela fuga sem rompimento com o sistema, não radical e transitória. O escravo fugia para batucar, namorar, beber, em suma, divertir-se. Ao ser capturado, ele passa a angariar fundos para a compra de sua alforria, sugerindo que o escravo tomou consciência do seu estado de objetificação, e da perspectiva de mudança. A partir daí surge, no enredo do Nêgo Fugido, a negociação, a busca por transformação da sua condição de propriedade. Outro tipo de fuga, a de rompimento total, acontece concomitantemente ao processo de negociação do conflito (Ramos, 1996).
} 
ensanguentada de anilina vermelho sangue, espingardas, charutos e vários outros elementos de cena, personagens dos escravos fugidos, conhecidas como as "nêgas" 5 , os caçadores, o capitão do mato, os policiais, a madrinha e o rei compartilham o palco pelas ruas da cidade.

A manifestação transforma a tragédia histórica do processo de escravidão em um enredo de triunfo em que os descendentes são empoderados pela narrativa. Na dramatização, seus ancestrais cativos alcançam a liberdade depois de muita resistência e luta contra o colonizador. A performance é vivida na atualidade através da memória coletiva incorporada e comunicada pelos participantes de forma emotiva; encenada na dança, na música, no figurino, na pintura, no grito. Fazem parte do repertório atual do grupo cenas e músicas que tratam de temas como trabalho na lavoura de cana, relações entre os donos de escravos e os escravos, relações entre os escravos e o ambiente, liberdade e abolição, etc. A maioria das crianças encena a nêga, principalmente, apesar de existirem caçadores e rei performatizados por elas, eventualmente. No âmbito de como a performance é vivida pelas crianças, a fala e o significado verbal do que é cantado parece ter menos poder de concretização da experiência sensorial do que a performatividade física, que ganha força na demonstração de conhecimento e no modo de aprendizagem corporal. Tendo em vista que assumi o uso da câmera fotográfica como instrumento de pesquisa, compreendi que era da relação entre eu, a criança e a câmera que surgiam essas performances e os dados etnográficos. A minha presença com a câmera era um dispositivo para que as crianças acionassem uma performatividade de si frente à situação, seja durante a apresentação do Nêgo Fugido, seja no cotidiano.

Hoje é muito difícil precisar, oficialmente, a quantidade de pessoas que participam do grupo. Em um dia de apresentação na rua é possível observar aproximadamente 30 a 60 pessoas, contando com organizadores, ajudantes e atores. Há alta rotatividade, e novos participantes ingressam de um dia para o outro, ou se retiram da apresentação até mesmo durante a execução da performance. Não há obrigatoriedade de participação em todos os domingos, o que garante muitas vezes a renovação dos participantes. É majoritariamente composto por homens e meninos. As meninas e as

\footnotetext{
${ }^{4}$ Muitas comunidades negras adotam a pintura preta do rosto ou do corpo inteiro como parte expressiva

de algumas manifestações da cultura popular, tanto no Brasil, com o Lambe Sujo de Sergipe, como em outros países, com o Son de Negro da Colômbia, e o Mandinga de Cabo Verde. Os seus sentidos são diversos. Cada significado condiz com o contexto local em que é expresso.

${ }^{5} \mathrm{~A}$ forma coloquial é justamente o nome dado à personagem. Doravante não usarei mais aspas.
} 
mulheres são minoria. Ao longo dos anos, o número de crianças tem crescido. Em todo caso, é importante dizer que existe o afastamento de algumas delas. $\mathrm{O}$ envolvimento ou a adesão religiosa às congregações evangélicas é uma das razões que têm garantido o distanciamento das crianças das manifestações da cultura popular local.

De modo geral, é possível perceber que há relação de consanguinidade entre alguns participantes. Existem muitos pais, sobrinhos, tios, filhos e netos, ou irmãos que se engajam no Nêgo Fugido juntos. É forte a prevalência de integrantes moradores de uma mesma região da vila, compondo uma rede de vizinhos e parentes. Entretanto, nenhuma dessas características identificadas no grupo surge como critério explícito de seleção de participantes. Normalmente as crianças decidem entrar no grupo por conta própria, sozinhas ou pedindo aos responsáveis legais que as levem.

Dentro do complexo mosaico de movimentos, formas, texturas e cores que o Nêgo Fugido oferece ao nosso campo de visão, fotografar parecia destacar aspectos particulares do evento, singularidades e pessoas-personagens (Gonçalves, 2012) que transcendiam à cena e proporcionavam outras reflexões sobre a construção daquela realidade. Neste caso, as crianças suscitavam questões em suas performances. Como aprendiam a fazer o que estavam fazendo? O que aquilo dizia sobre a existência delas? $\mathrm{O}$ que elas estavam mostrando de si e da comunidade como um todo através de suas performances?

As crianças de Acupe desde muito pequenas participam do Nêgo Fugido. Ainda no colo dos mais velhos, elas assistem às apresentações na porta de casa, pela janela, ou em trânsito pelas ruas e vielas. Assistir à apresentação é participar também, em certa medida. Ao longo das tardes de domingo, são elas, principalmente, o foco das investidas aterrorizantes dos caçadores, que avançam sobre umas e outras, com suas expressões faciais grotescas, recurso dramatúrgico e estético característico da manifestação. As crianças vêem acontecer nas ruas de sua pacata cidade a performance de uma ameaçadora caça e posterior venda de pessoas negras em agonia e estado de objetificação, amarradas pelo pescoço e mãos, e conduzidas à corda curta. Algumas delas também crianças. Crianças assistem crianças. Era comum que algumas ficassem com medo de outras. Muitas choravam, gritavam, escondiam-se por detrás de adultos, corriam apavoradas para dentro de casa, faziam cara de asco e ficavam em estado evidente de apreensão. 
Richard Schechner (2011), ao tentar definir pontos de contatos entre a antropologia e o teatro, explica que o exercício de performatizar altera, permanentemente ou temporariamente, aqueles envolvidos no evento. Isso cabe ao ator que performatiza no âmbito de um teatro, para quem participa de rituais em larga escala, com ou sem transe, assim como quem assiste enquanto audiência. Mais tarde, em outro escrito que atualiza suas reflexões sobre a conexão entre ambas as áreas, ele reitera seu argumento dizendo que o cérebro é o lugar de performance (Schechner, 2011). Para ele, as emoções são físicas, incorporadas e contagiantes. O órgão responsável pelo vínculo entre aquele que expressa corporalmente e aquele que assiste é o cérebro, por ser situado cultural, biológica e socialmente. De modo poético, ele diz que "nosso corpo não acaba em nossa pele. Ele vai além, chegando até o cérebro dos outros" (p.58) traduzindo que, tanto expectadores quantos atores experimentam a ação. Os atores sociais performatizam em sua imaginação juntamente com quem observa. O evento não acontece só visualmente, mas é uma experiência tentacular que atinge todos os sentidos e desencadeia transformações múltiplas em todos os seres envolvidos (Schechner, 2011). Tentando ampliar essa discussão, Schechner (2011) indica haver certa autonomia entre cada experiência. Cada performance é conectada ao espectador que as ouve e a elas assiste de modo muito específico. Essa relação é particularmente definida entre os atores e para "aqueles-para-quem-a-performance-existe" (grifo e termo do autor).

Enquanto nêgas, as crianças fazem a sua performance dando continuidade à manifestação cultural. Há imitação, repetição e criação de movimentos, de partituras corporais e improvisação de cenas. É como nêga que as crianças aprendem como fazer parte do Nêgo Fugido, conhece as regras explícitas (quase sempre não seguidas), os hábitos, até as normas tácitas e o respeito aos cargos na hierarquia do grupo. É ouvindo e fazendo (Ingold, 2008), vendo e fazendo (Pinto, 2014), sentindo e fazendo que as crianças se apropriam da tradição, concretizando a aprendizagem situada na prática social (Lave, 1991; 1992).

Tim Ingold (2008), que em seu trabalho sobre a percepção sensorial identifica que os sentidos da visão, audição e tato ocupam uma posição de destaque no apreender dos seres humanos. Os órgãos dos sentidos são veículos fundamentais de construção de saber de si e do mundo, e a mente e a cognição são outras ferramentas do processo. $\mathrm{O}$ autor não vê os sentidos como fruto exclusivamente dos órgãos, mas algo que conecta corpo e mente. $\mathrm{O}$ autor argumenta que a "atenção sensitiva se encontra no ápice do 
movimento do vir a ser no mundo" (Ingold, 2008: 4). A partir disso, ele indica que a visão e a audição são processos de percepção conjunta que forjam o conhecimento sobre mundo, fundado pela experiência sensorial. De modo sucinto, o antropólogo repensa, a partir de outros autores, o lugar do olhar e do escutar nas práticas e nos sistemas sensoriais de sociedades ocidentais e não ocidentais, principalmente no que tange à luz e ao som na experimentação do mundo. Sabemos que aquilo que vemos e ouvimos são nossas traduções, percepções das coisas e seres que estão e se manifestam no mundo. Ingold considera que os sistemas perceptuais funcionam de modo relacional entre o cérebro, o corpo e o mundo. Não haveria uma operação interna, ou mental, da qual as sensações seriam material bruto. Há uma incorporação do conhecimento através todas as faculdades sensitivas e percebidas, indissociáveis na percepção.

Seu escrito se desdobra na análise de outros sentidos humanos, como o tato. Recorro às conclusões de Ingold para embasar o argumento de que o conhecimento sobre o Nêgo Fugido perpassa várias formas de aprendizagem que envolvem os sentidos e o engajamento total do corpo na construção de uma percepção de si e de mundo.

[Ingold afirma preponderantemente que] os sistemas perceptuais não apenas se imbricam em suas funções, mas também se submetem a um sistema total de orientação corporal. Olhar, ouvir e tocar, portanto, não são atividades separadas; elas são apenas facetas diferentes da mesma atividade: a do organismo todo em seu ambiente (Ingold, 2008: 17).

Jean Lave (1991, 1992), antropóloga estadunidense, em seus estudos indica que os modos de aprendizagem situada são expressão da existência social de um grupo. As bases da teoria formulada pela autora definem que os grupos sociais aprendem somente quando vivem os saberes na e em prática. Desse modo, a aprendizagem é um processo de transformação e formação de identidade contínua. Lave considera que pesquisas preocupadas em compreender a aprendizagem realizada em escolas podem restringir bastante uma experiência tão múltipla e fundamentalmente social a um único modo de aprender. Nas escolas, o fundamento da aprendizagem está na relação de ensino, em que a forma de aprender ensinada exige que um mediador ensine algo a quem não sabe, os estudantes.

Na experiência cotidiana, argumenta Lave (1991, 1992), a aprendizagem é um fenômeno extremamente complexo que acontece de várias maneiras durante as vivências práticas de um grupo social. A conexão entre o aprendiz e o que é aprendido está na 
relação entre eles, no modo como socialmente a comunidade se estabelece em sua prática social. A perspectiva analítica marxista proposta por Lave (1992) não identifica a aprendizagem como um fenômeno individual de internalização cognitiva de um conhecimento social. Ao invés disso, a autora afirma que aprender é torna-se membro de uma comunidade de prática, ao mesmo tempo em que é desenvolver uma habilidade e um conhecimento prático da comunidade.

A condição de alienação de saberes e práticas sobre si e sobre o mundo foi imprescindível para a manutenção do capitalismo nos últimos anos. Assim, Lave acredita que "aprender identidades" passou por um perverso percurso de "desfiguração" e "mercantilização" (termos da autora). A aprendizagem virou uma commodity, um produto específico e singular, transformado em um conhecimento de poucos, destinado ao comércio. Entretanto, no dia-a-dia, aprender abarca uma multiplicidade de formas, e é contextualizado na história do grupo social em que se situa. A aprendizagem não é uma habilidade espacial que requer uma especialização institucional.

Viver o Nêgo Fugido a partir da experiência das crianças e investigar como elas aprendem a fazer parte da manifestação fez com que eu percebesse que, naquele contexto, as crianças aprendem a aprender de inúmeras formas, utilizando o corpo inteiro. A visão, a audição, o paladar, o olfato, o tato, a mente, tudo é acionado durante performance e a performance aciona todo o corpo para se concretizar, num ciclo permanente de aprendizagem e prática, e de prática social e aprendizagem. Isto revela algo sobre suas identidades, de como as crianças constroem a si mesmas. Desse modo, a as reflexões de Lave indicam que a compreensão do processo de aprendizagem situada socialmente revela uma ontologia social. O sujeito que aprende não está simplesmente envolvido em uma relação de aquisição de conhecimento, mas é um ser em relação com mundo, formando a si mesmo e o que existe ao seu redor. O seu jeito de aprender evidencia como sua identidade está engajada histórica e culturalmente em seu contexto particular. No caso das crianças do Nêgo Fugido, aprender com o corpo inteiro fala sobre a capacidade de interação e integração das pessoas entre si e com o mundo. Ou ainda, sobre a reprodução de uma tradição através da formação de identidades que a transforma e a eterniza. .

Michael Taussig (1993) argumenta que a habilidade de copiar e mimetizar o outro é uma forma de adquirir, de uma maneira subversiva, o poder que este detém. A mágica da transferência do poder daquele que é reproduzido para aquele que reproduz 
deriva da faculdade peculiar e visceral mimética de desfazer uma alteridade, transformando sujeitos muito diferentes em semelhantes, ou o inverso (Taussig, 1993). Richard Schechner $(2006 ; 2011)$ comunica que, no âmbito da performance teatral, a reprodução dada pela repetição em ensaios permite que a apropriação e domínio da técnica se transforme em liberdade criativa, construindo uma base para a mudança experimental e transgressora. O que observei em campo é que cada criança faz a cópia do seu jeito, em um modo próprio de transformar criativamente uma performance que está circunscrita pela tradição. A ordem cultural é ambivalente, e implica nas regras e na transgressão (Clifford, 2008). Por isso indico que, no Nêgo Fugido, transgredir o modo de fazer pode significar transcender a forma, mas também pode completar uma interdição tácita.

Sob a perspectiva da apreensão de um conhecimento a partir das percepções sensoriais envolvendo a audição, visão, tato, paladar, e imitação corporal do comportamento do outro, Michael Taussig (1993) desenvolve melhor o termo "mimese" para falar dessa reprodução como prática social em relações assimétricas de poder. $\mathrm{O}$ autor fala que a constituição da alteridade pode ser construída através de um saber sensorial em que, nesse contexto, a mimese é a brecha para a resistência e transgressão à colonização. O ato de copiar o colonizador oferece aos colonizados um modo de se apropriar de sua força, desencadeando um movimento de descolonização do imaginário, de sua história e de seus corpos. Configura-se como um ato de produzir uma memória inscrita no corpo, que gera uma resistência política e cognitiva que proporciona reflexibilidade naquele que performatiza o outro (Taussig, 1993). Por isso, a apropriação mágica do outro é considerada pelo autor como um poder. Para ele, as pessoas que replicam produzem semelhanças e diferenças ao objeto replicado através de uma relação sensorial entres as partes. Esse poder de incorporar a alteridade é expresso pela performatividade do corpo por inteiro.

A descolonização que Taussig (1993) fala é concretizada quando a imitação dá a possibilidade àquele que a executa de adquirir as habilidades, qualidades e poder daquele que é copiado, expressando-se como espelho reconfigurado poderoso e efetivo. No Nêgo Fugido, existem vários tipos de mimeses. As crianças não só copiam os adultos ou elas próprias na encenação dos escravos e caçadores, mas se apropriam e constroem no corpo, de forma exagerada e intensa, concomitantemente, um imaginário através de imagens de valores e habilidades do outro que as intimida, objetiva e 
subjetivamente. Por outro lado, elas expressam também elementos performativos hiperbolizados que surgem da negociação identitária que elas vivem e experimentam no dia-a-dia. No processo de descolonização proporcionado pela manifestação do Nêgo Fugido, as crianças se constituem como sujeitos que reivindicam real liberdade de existência e igualdade racial, em uma sociedade que historicamente tem subjugado a sua identidade racial à condição de invisibilidade e subalternidade, e tem desvalorizado, no âmbito ideológico, político e epistemológico, o legado cultural afro-brasileiro.

\section{O agenciamento das crianças na performance do Nêgo Fugido}

"Habitar um tal mundo não é se deparar com um espaço de objetos prontos, mas participar de dentro no movimento perpétuo de sua geração" (Ingold, 2008: 7). No Nêgo Fugido existem outras maneiras de assistir participando. Geralmente em coro, crianças de todas as idades, gritam para um grupo que passa encenando: "Sortá a nêga, iaiá!"; “Pega essa nêga, iaiá!”. Elas estão querendo chamar a atenção daqueles que estão se apresentando, num misto de expressão de coragem e de medo, por estar na rua desafiando verbalmente a personagem. Em resposta, nêgas e caçadores correm, ameaçam pegar as crianças, sujar todos de carvão e anilina, ou incitar outros medos que moram no imaginário delas. Algumas crianças que nunca performatizaram uma personagem contaram que os caçadores atiravam feijão de suas espingardas adaptadas, ou outras diziam que eles assustavam com tanta feiura. Isso acrescenta ainda mais fluidez e dinâmica à encenação, que passa pelas ruas com direcionamento dramático (quase) definido na construção das cenas. A manifestação normalmente dá abertura às improvisações que vão surgindo à medida que eles estão no jogo entre si e com a audiência. Nesse sentido, a audiência é participante, e as crianças mais notavelmente.

William Corsaro (2009) analisa uma brincadeira intitulada por ele como "aproximação-evitação", possível de ser comparada com o jogo acima relatado. Nesse contexto, existe a fase de identificação, que consiste em criar ou descobrir a personagem ameaçadora; a fase de aproximação, em que as crianças provocam a personagem ameaçadora através de gestos, vocalização, ou tentando aproximar-se cuidadosamente; a fase de evitação, em que a personagem ameaçadora descobre a presença das crianças e, em contrapartida, estas depositam sobre a primeira um poder perante o grupo, fugindo para um lugar seguro; e, por fim, as crianças ficam livres da personagem ameaçadora, 
uma vez que alcançam o lugar seguro. Corsaro (2009: 34) interpreta o jogo da seguinte forma:

As crianças produzem coletivamente uma rotina na qual compartilham a acumulação de tensão, a excitação da ameaça, e o alívio e a alegria da fuga. As representações sociais de perigo, mal, desconhecido e outras ambiguidades, que estão se desenvolvendo nas crianças, são mais firmemente apreendidas e controladas.

Geralmente, as crianças que encenam alguma personagem na manifestação antecipam sua ida à sede, antes das apresentações. São elas as primeiras a chegar: os meninos sem camisa e descalços, as meninas somente com a roupa do corpo. Do outro lado da rua, onde a sombra tem vez, os meninos se apoiam nas paredes das casas de vizinhos, sentados nos muros em construção. Somente mais tarde chegam os adultos - a comissão organizadora da manifestação (figurinos, instrumentos, etc.), os tocadores e cantadores, e os atores que encenam os caçadores, o capitão do mato, o rei e os policiais. Depois de toda a preparação, distribuição de figurinos e pintura corporal, a performance inicia, e as crianças ficam atentas umas às outras, mais velhas e mais novas.

A dimensão do fazer próprio, ou seja, de mudar a performance, personalizar os movimentos e encenações, muitas vezes é encarada por alguns adultos como desobediência. Não há a mera imitação, mas um processo de aprendizagem-observanteatuante, um modo autônomo de aprender e compor a manifestação a partir do que já existe e já é tradicional no fazer. Eles se engajam na dança, mantendo a atmosfera sombria e catártica do Nêgo Fugido com comprometimento. Muitos zelam pelo espaço de apresentação, retirando as pedras, garrafas, restos de vidro do lugar, para que não haja acidentes e machucados na cena em que todos se jogarão no chão. Eles se desafiam e ao mesmo tempo mantêm um comportamento cuidadoso com as crianças menores, respondem alto ao coro, e criam suas intervenções próprias sobre a estrutura performática do Nêgo Fugido.

São frequentes as reclamações sobre as crianças que participam do Nêgo Fugido. Presenciei brigas homéricas e acusações de mau comportamento por parte de adultos e organizadores da manifestação, assim como da audiência. A minha percepção, entretanto, indicava outra coisa. $\mathrm{O}$ que observei foram crianças muito comprometidas com a tradição; e pessoas dispostas a suportar quatro ou cinco horas de esgotamento físico através das dança, corridas, empurrões, embates corporais da performance, tudo 
com força e entusiasmo. Algumas crianças cansavam e se sentavam à beira das calçadas, outras esmoreciam pela rua, deitando seus corpos esgotados no chão. Muitas retomavam a encenação, sejam motivadas por adultos ou pelo contexto efervescente das ruas no domingo de festa. Havia irreverência e muita autonomia no modo de encenar o Nêgo Fugido.

À medida em que passam mais tempo no grupo, ou ficam mais velhas, as crianças podem galgar encenar outras personagens. Entretanto, sempre que conversava sobre a possibilidade de sair como outra personagem, muitas crianças diziam que gostavam de fazer a nêga, e que não tinham vontade de ser o caçador, o capitão do mato ou o guarda. Quase nenhuma se referia ao rei, posto que é dado a elas que o rei tem que ser branco, ainda que fenotipicamente isso não se dê dessa forma. Todos os reis que vi na encenação eram negros de pele clara. Talvez por isso fossem considerados brancos para aqueles que explicavam o critério de encenação da personagem. Ser branco é hoje um fator de distinção do rei. Ele, os guardas e o capitão do mato não têm a pele pintada de carvão. Ramos (1996), no tempo de sua pesquisa, reconstituiu a história de vida de alguns participantes mais velhos, hoje falecidos. A autora conta que o rei chegou a ser performatizado por Seu Esmeraldo, importante colaborador e organizador da manifestação, cuja casa funcionava como sede permanente do grupo, tal como acontece com a casa da atual madrinha, Dona Santa. Hoje Rafael é o único menino que performatiza o rei. Ele confessou não gostar de fazer a personagem. Presenciei o seu desconforto em calçar sapatos, e em vestir todas as camadas de roupas que a fantasia demanda. Indumentária oposta à caracterização da nêga, que veste somente um short e a pintura corporal.

Tive a oportunidade de conversar melhor com as crianças que saem de nêgas sobre o seu fazer, suas preferências e seus desagrados em relação à participação no Nêgo Fugido. Muitas delas apontaram para a apreciação da dança, principalmente os meninos. Rafael contou apreciar "brincar, ficar pintado também, tocar atabaque e se jogar no chão" 6 . Eu observei que muitas se engajam sobremaneira na performance, nos movimentos, na dança, com muita força física, seriedade e fé cênica. Eles parecem encarnar a personagem ininterruptamente, mesmo quando não estão dançando em roda, cantando ou fazendo a cena da mendicância pelas ruas. Há um estado de prontidão

\footnotetext{
${ }^{6}$ As nêgas não tocam atabaque durante a encenação, mas as crianças experimentam toques nos instrumentos durante o aquecimento dos tambores.
} 
acionado durante a apresentação que se faz e se desfaz com muita fluidez e instantaneamente.

Normalmente as nêgas mendigam para comprar a carta de alforria. Elas podem estar acompanhadas pelo caçador ou não. O modo de pedir dinheiro das nêgas é despertando a piedade da audiência, com simulacros de choro, de desespero e de angústia para que, padecidas pela condição do sofrimento do escravo, as pessoas contribuam com algumas moedas para a compra da liberdade. Muitas vezes a audiência é ameaçada pelo caçador. Comumente as pessoas dão dinheiro menos por compadecimento. Os expectadores riem da performance do ator, ou porque os conhecem, assegurando que a performance catártica é encenação, ou porque a performance mistura expressividades ambíguas como comicidade e medo do grotesco, numa mistura irônica de riso e repulsa.

Renato Sztutman (2009) entende ser a ironia e o exagero marcas primordiais que revelam a aproximação da antropologia feita por Jean Rouch à estética surrealista. Partindo da análise de Sztutman (2009) e Gonçalves (2009) sobre Os Mestres Loucos, arrisco afirmar que a performance do Nêgo Fugido têm também aproximação com a expressividade surrealista ${ }^{7}$. A manifestação transpõe barreiras da consciência e da linearidade do cotidiano, configurando-se como um evento alegórico, de intensidade, não de rupturas. A manifestação do Nêgo Fugido dá grande importância às emoções na construção da performance, e recorre à ironia alcançando críticas às estruturas (neo) colonialistas. Os participantes vivem o transe em certa medida, e investem no descontrole do corpo e no exagero como maximização dos sentimentos e das sensações. Compartilhando destas características surrealistas, a manifestação tem apelo estético, e justapõe o belo e o feio, o normal e o repugnante, transbordando a realidade e a verossimilhança, com extraordinária dimensão de improvisação, causando transformações nos participantes e arrebatação súbita no encontro com a audiência e com a alteridade.

Quando perguntadas sobre a manifestação, as crianças não verbalizavam o que sabiam. Ao invés disso, elas performatizavam. Usavam o corpo para descrever o que entendiam (Pinto, 2010), fazendo caretas, revirando os olhos ou dançando trechos da

\footnotetext{
${ }^{7}$ Produção de Jean Rouch de 1954 sobre a cerimônia Hauka, vivenciada pelos Songhay, do Niger. Tal filme etnográfico é referência na etnografia audiovisual, e trata de temas caros à Antropologia, como possessão, colonialismo e vida pós-colonial, através da exibição do ritual em que homens são possuídos por espíritos de administradores coloniais.
} 
manifestação. A história da escravidão e a percepção dos interlocutores sobre essa história está engendrada na performance. O conhecimento não é falado, nem rememorado verbalmente, sem a performance. Ele é aprendido e ensinado através dela. A história é rememorada através da performance de sofrimento, de resistência e de luta pela liberdade. Os corpos das pessoas do Nêgo Fugido são o livro que guarda o conhecimento sobre a história da abolição da escravidão e da manifestação no Recôncavo Baiano.

Em outras oportunidades, as crianças também revelaram não gostar de alguns momentos da performance. Como quando são empurradas umas pelas outras ou pelos caçadores durante a dança em roda, o que Rafael chama de "empurra-empurra". Octávio, uma criança negra de 10 anos que mora com a avó e a irmã ainda bebê, apresentou aborrecimento ao contar sobre sua experiência. Não gosta quando: “os caçador chega correndo e tomba [em mim $]^{8}$. Outro dia eu caí ali, e eu nem vi quem foi.

Um me dá tombo aqui, outro me dá tombo nas costas" [sic]. Octávio é integrante do Nêgo Fugido desde os oito anos. Todos os anos ele brinca de nêga junto com outros dois primos. É bem verdade que as versões sobre as relações internas do grupo Nêgo Fugido não se esgotam por aí, mas é notável que as crianças não gostam de tudo que vivenciam na performance do grupo.

É no movimento rítmico e na dança que também ocorre a construção básica da cena da performance do Nêgo Fugido. Antes de começar a festa, ouvi Rafael conversando com outras crianças, demonstrando grande alegria ao ver o retorno de um caçador antigo. Voltei minha atenção ao enérgico diálogo entre as crianças para entender o que estavam falando. Rafael dizia que "aquele sabe brincar direito" [sic]. E emendou: “Ele chama atenção [...]!’’[sic]. Talvez o conhecimento performático seja elaborado nesse potencial de chamar a atenção da audiência com a encenação, com as distorções faciais, com todos os recursos cênicos e movimentos. Outra criança acrescentou que "quem brinca melhor é quem dança melhor, mas não tem um modo de dançar único" [sic]. Isso pode indicar o que eles dão mais importância, e em que eles investem sua energia na performance da manifestação. Mais uma vez reitero meu argumento: No Nêgo Fugido, o conhecimento das crianças é adquirido e expressado através do corpo e da performance; ele é dançado.

\footnotetext{
${ }^{8}$ Tombo pode significar esbarrar em algo ou alguém, empurrar, e/ou cair no chão.
} 
O rosto e o peito das nêgas são tela para os desenhos e pintura corporal que compõem o cenário plástico do Nêgo Fugido. O desenho e a pintura formam o corpo dos atores, e as personagens. Todos os escravos fujões têm seus rostos pintados de preto, assim como os caçadores. Após vestirem os figurinos, o carvão moído e o óleo de cozinha são as tintas que demarcam a segunda fase da transformação das crianças em nêgas. Ao assistir uma criança tirar o excesso de óleo e carvão do rosto para desenhar linhas pretas no abdômen e no braço, na região do bíceps, perguntei o porquê de desenhar esses traços naquela parte do corpo. O menino disse que era para ficar mais "catigoria" [sic]. Fiz uma pergunta parecida à outra criança com quem tinha estabelecido um diálogo mais frequente. Ela desenhava no abdômen uma seta entrecruzada por traços que apontava para cima, talvez para o rosto dele. Perguntei o que significava aquele desenho, e ele respondeu: "É o Nêgo Fugido".

\section{Mosaico 1}

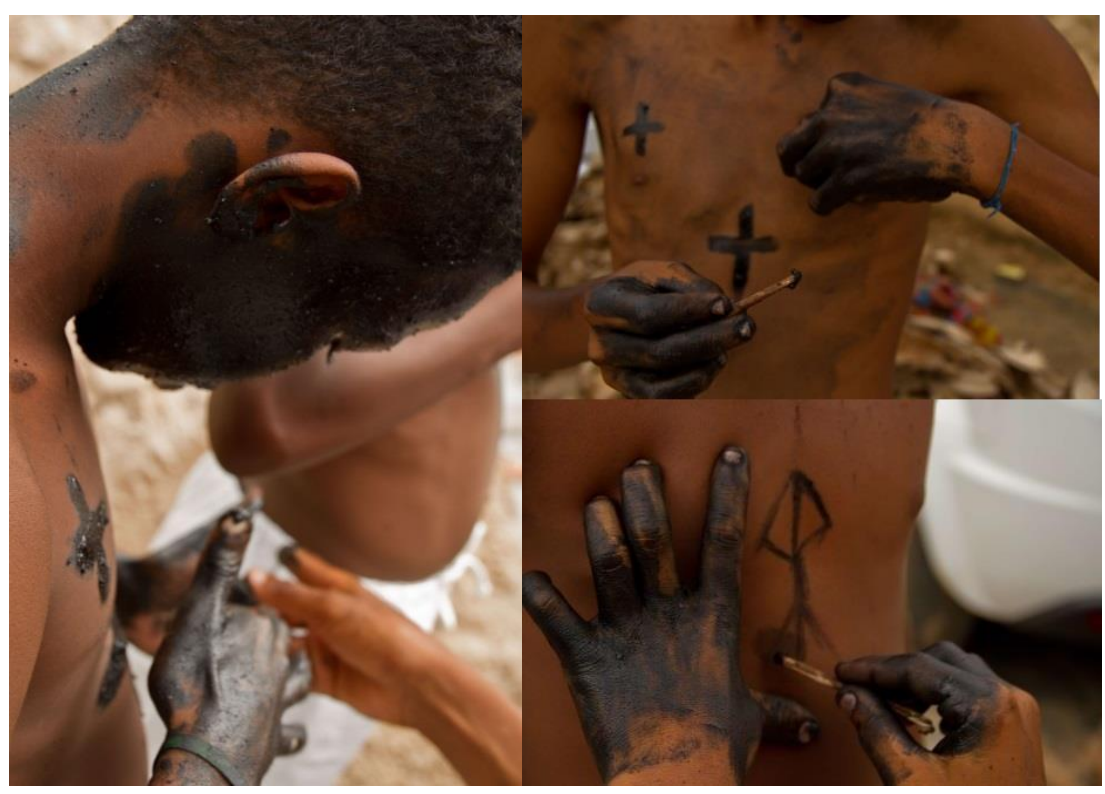

Mosaico 1: Além dos rostos, os meninos experimentam pintar o pescoço, parte do tórax com cruzes, xis e outras formas que criam na hora.

Fabiano, 9 anos, um menino de corpo muito franzino, pedia a uma ajudante do grupo: "Pinta mais, pinta tudo. Hoje quero pintar o corpo de todo". É depois da pintura que as crianças começam a expressar os trejeitos de sua personagem. Elas começam a fazer os movimentos, ensaiando trechos de danças, revirando os olhos, mostrando a língua e babando para os fotógrafos, audiência e entre si. 
Schechner (2011) recorre ao teatro nô para explorar o significado do uso da máscara e sua relação com o ator por debaixo dela para problematizar a habilidade do ator de transitar entre ser eu e ser outro. Ele tenta compreender o porquê do uso, nesse teatro, de uma máscara feminina pequena que deixa evidente o que há por detrás da máscara ilusória: o rosto largo de um ator homem. A máscara exibe o processo de transformação que a fantasia cria. O escrito de Schechner indica que mostrar um pedaço do rosto por baixo chama a atenção para o fato de que o que vemos em cena é a personagem e o ator ao mesmo tempo. Ou seja, as fronteiras entre o eu e o outro são transbordadas, ampliando o impacto da performance. No Nêgo Fugido, parece que acontece o movimento inverso. Para as crianças que desejam pintar todo o corpo, expandir o alcance do carvão para além do rosto e fazer outros desenhos talvez seja, potencialmente, assumir mais o outro que irão performatizar. Deixa de ser ele mesmo, e ser a nêga por inteiro, nos moldes que todos compartilham no imaginário coletivo da manifestação. $\mathrm{O}$ ator social que performatiza uma personagem alcança outro lugar do ser que não é aquele em que ele vive (o ser eles mesmo), e não é completamente a outra personagem (o não ser ele), mas um espaço entre personas (Schechner, 2011). Neste sentido, Fabiano, no Nêgo Fugido, também vive uma condição de ser e não ser ele mesmo. Ser Fabiano e ao mesmo tempo ser a personagem ancestral, a nêga. E se coloca em outro lugar de existência da sua persona.

Renato Stztuman (2009: 116) afirma que a "equação entre loucura e civilização é justamente o que indica o lugar reflexivo do ritual". Recorro à citação de Sztutman (2009) mais uma vez sobre o filme Os Mestres Loucos por ver mais uma possível analogia com a manifestação do Nêgo Fugido:

Esses rituais se revelam por sua imensa capacidade criativa, criação antes de tudo como transformação e reapropriação de elementos inscritos na experiência. Os rituais de possessão ensinavam a Rouch que para viver nesse mundo e compreendêlo era preciso evocar outro, povoado de deuses, espíritos e forças que não cansam de se transformar e que têm de ser constantemente reinventados (p. 117).

No Nêgo Fugido podemos observar a expressão de uma memória inscrita no corpo, em que crianças negras performatizam dores e flagelos que nunca vivenciaram, mas que estão na performance criativa e triunfante da memória da manifestação. Além de ter um papel importante na descolonização do imaginário (Taussig, 1993), a manifestação é uma construção estética em que os participantes transformam em catarse 
todo o sofrimento ancestral perpetrado pelo trauma cultural da escravidão (Eyerman, 2004).

Durante a encenação, de rosto, pescoço e tórax pintados, Fabiano surpreende em sua performance de nêga. Ele é impávido. Talvez o seu miúdo tamanho engradeça a sua performance. Dentro de casa, ele e seu irmão caçula gostavam de assistir televisão deitados compartilhando o sofá. Em posição invertida, um coçava a perna do outro, num ato carinhoso de ninar mútuo. Nem parece o mesmo menino que dança sem cansar, simulando a dor da agonia do escravo punido com grande "fé cênica". Seu olhar perdido nos momentos de ápice do sofrimento do escravo, ou os olhos a tremelicar dentro da cavidade ocular, sua capacidade de "ficar morto" sem sair do estado estático e visceral, a força com que seu corpo magro mantem as cenas e a sequência de movimentos, o jogo de cena que faz com outros brincantes mais velhos, a capacidade criativa de improviser sem vergonha ou medo: tudo constrói uma atmosfera que nos transporta para outro plano.

Por outro lado, ensimesmado, Fabiano performatiza de modo excêntrico, como se estivesse em transe, sem conexão com o grupo, à parte do que os outros estão fazendo ao redor. Isso, entretanto, não parece um alheamento, mas um engajamento profundo e hermético. Ele sabe como e o que fazer; o que parece é que nesses momentos Fabiano sente corporalmente o que está expressando artisticamente. Fabiano, enquanto ator tem dentro de si aquele estado no qual o ritual se intensifica, em condição latente, como em um imaginário coletivo, e uma memória compartilhada pela comunidade através do corpo. Ron Eyerman (2004) trabalha o conceito de trauma cultural na sociologia a partir da construção da noção de identidade coletiva afroamericana derivada da rejeição que a população negra vivenciou na sociedade após a promessa de reintegração promovida pela Guerra Civil de 1861 nos Estados Unidos. A escravidão, no contexto posterior, foi crucial ao processo de formação de identidade coletiva, muito mais como uma memória do que aconteceu do que como uma experiência em si. O termo trauma cultural carrega consigo uma dupla conotação, individual e coletiva. Enquanto uma resposta emocional à situação que afeta profundamente o ser, o trauma cultural conecta membros que compartilham da memória de uma tragédia para mobilizar indivíduos à coesão. O autor fala que o processo de aceitação do trauma requer tempo, mediação e representação. Justamente por isso o momento de crise não precisa ser vivenciado por todos os sujeitos, mas reverbera na 
identidade e no imaginário das gerações futuras, deixando marcas indeléveis, efeitos negativos na consciência do grupo, violando sua existência cultural (Eyerman, 2004). A memória coletiva é fundamental para a construção da personalidade e formação social, pois "orienta o grupo promovendo um mapa cognitivo e temporal" (p. 161) e reconecta pessoas distantes no tempo e no espaço.

Todos os grupos acham mitos, histórias que contam quem somos nós através da narração de onde viemos. Tal narrativa forma "marcos de referência" que são passados de geração a geração pela tradição. Rituais e cerimonias, performances públicas reconectam grupos e confirmam a identidade que os compõem (Eyerman, 2004: 162) (tradução livre da autora).

O Nêgo Fugido transforma a tragédia histórica do processo de escravidão em um enredo de triunfo em que os descendentes são empoderados pela narrativa. Na dramatização, seus ancestrais cativos alcançam a liberdade depois de muita resistência e luta contra o colonizador. O trauma cultural é vivido na atualidade, e tal memória coletiva é comunicada pelas crianças em sua performance emotiva; expressada através da dança, da música, da pintura, do figurino e do grito.

Mosaico 2
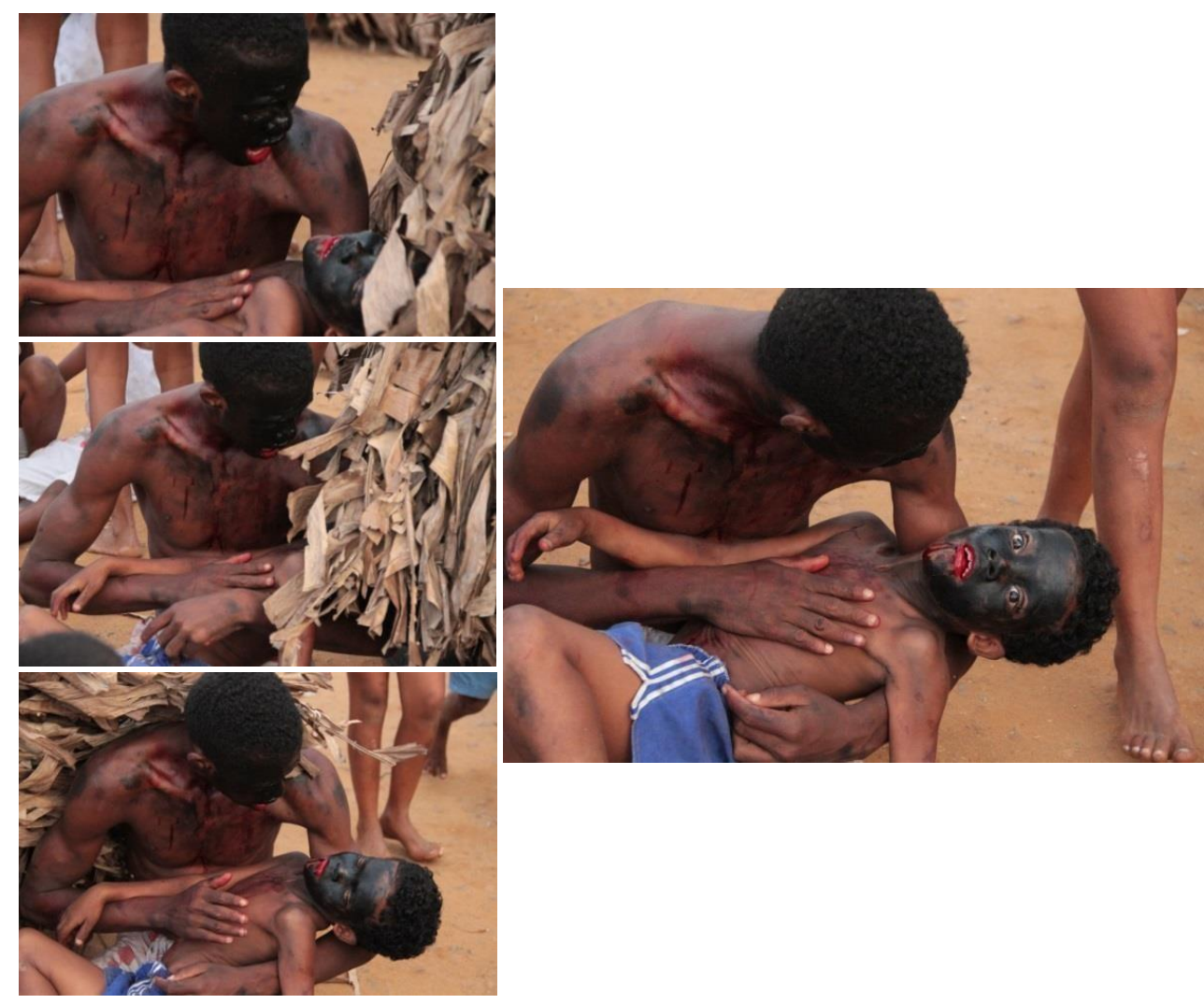
Os olhos de Fabiano, como mostra o mosaico acima, são expressivos de modo que assusta mesmo quem já assistiu a apresentação inúmeras vezes. A dramatização do menino impressiona particularmente porque parece não haver momentos de apatia. $\mathrm{O}$ coletivo de crianças têm uma atitude propositiva na performance, e certa autonomia na improvisação. Mas Fabiano sensibiliza de um modo peculiar. Afetada, muitas vezes me vi tentada a intervir na apresentação e acudi-lo. Após ver a performance de Fabiano, perguntei-me o que seria acionado nele para que o menino tímido, que ainda chupa dedo, se transformasse em um ator/performer de nêga tão convincente. Schechner (2011) aciona dois universos da experiência do ator para tentar explicar o que acontece com o ator no ato performático. Acompanho uma longa citação que dá conta de sua reflexão.

[Há] o mundo da existência contingente como objetos e pessoas comuns e o mundo da existência transcendental como implementos mágicos, deuses, demônios, personagens. Não é que um performer deixa de ser ela ou ele mesmo quando ela ou ele se tornam outros - eu's múltiplos coexistindo em uma tensão dialética não resolvida. Assim como uma marionete não deixa de ser "morto" quando é animado, o performer não deixa de ser, em algum nível, seu eu comum quando ele é possuído por um deus ou interpreta o papel [...] (Schechner, 2011: 216).

O que Schechner parece dizer é que existe uma transformação múltipla acontecendo. Fabiano aparenta ser uma nêga reencarnada em estado de catarse, e imagina a memória do sofrimento e do dia-a-dia de um tempo passado em que ele, enquanto criança, não viveu, mas seus ancestrais sim.

Gonçalves, Marques e Cardoso (2012) explicam que criar duplos de si ajuda a perscrutar o que seria o "eu". Seria um misto complexo de representações, apresentações e movimentos. Nesse processo, a junção entre ficção e realidade, e o poder da imaginação, potencializa ao máximo a construção da identidade e da alteridade entre os atores sociais. Personagem e ator social dialogam supreendentemente. É aí que, provavelmente, emerge o complexo jogo de reconhecimento de si. 


\section{A performance das crianças no encontro com a alteridade}

Estar com a câmera em mãos sempre despertava o interesse das crianças em mim, ou nas imagens que fazíamos juntas. Elas, geralmente, queriam ser fotografadas, fotografar e manusear os objetos que eu trazia comigo. Tanto na performance artística como em momentos cotidianos, meninas e meninos pediam para mexer na câmera, e demandavam que eu as fotografasse em certas poses durante a performance. Atenta a esse encontro, comecei a perceber que elas têm agência sobre a imagem que constroem de si, muito além do meu olhar através do visor óptico do equipamento. E o próprio equipamento faz fazer performances (no sentido latouriano de agenciamento). A agência dos não-humanos, para Latour (1996) está na medida em que eles produzem diferenças e fazem fazer. $\mathrm{O}$ autor argumenta que a forma de fazer pesquisa de campo em ciências sociais deve fustigar o fazer compartilhado, reconhecendo a agência dos humanos e não-humanos nas associações sociais e nos resultados das relações entre eles. Neste meu caso, na relação com a câmera.

As crianças, principalmente, relacionavam a minha presença com a câmera a outros fotógrafos, dentre eles muitos estrangeiros de outros países que iam fotografar as manifestações tradicionais do julho ou oriundos dos clubes de fotografia da capital do estado, visitantes assíduos da comunidade em dias de festa. Era como se todos nós, "os gringos", tivéssemos a mesma origem, falássemos uma mesma língua, representássemos um mesmo grupo. ${ }^{9}$ Havia ocasiões em que desconhecidos me abordavam na rua perguntando por outras pessoas, pesquisadores e principalmente profissionais do audiovisual que passaram por lá. Curiosamente, vez ou outra eu ouvia meninos conversando embolado, travando língua e criando palavras para conversar comigo, ou até mesmo falando inglês. Eu entrava na brincadeira, falando embolado também. "Entrar na brincadeira" despertou muitas aproximações, gerou muitas conversas e construiu uma relação de maior confiança em mim por parte de algumas crianças, de pais ou avós mais desconfiados.

A câmera foi responsável para que outras estratégias etnográficas fossem bem sucedidas ou viessem a falhar. Indo além das possibilidades de relações estabelecidas em campo, as fotografias posteriormente foram visitadas e revisitadas durante todas as

\footnotetext{
${ }^{9}$ Termo local para as pessoas estrangeiras à Acupe que portavam câmeras, mesmo sendo brasileiras. Muitas vezes fui chamada de gringa em campo.
} 
fases de feitura do trabalho. Estou me referindo à capacidade delas de agir como extensão da minha própria memória, como mecanismo desencadeador de questões ou reflexões nos interlocutores, e como recurso para a descrição etnográfica na narrativa fotográfica. Um determinado tipo de reflexão só se tornou possível neste trabalho graças à presença da câmera antes, durante e depois, e seus desdobramentos.

$\mathrm{Na}$ pesquisa, a câmera mostrou ser um equipamento que proporcionou a captação de uma realidade diferente da percepção humana. A assunção de um ponto de vista através da câmera fotográfica demarcou em mim a autoria do que estava sendo construído como imagem. É sabido que, enquanto pesquisadora com a câmera em mãos, o ponto de vista adotado na construção da imagem e o posterior relato sobre a experiência desse encontro são filtrados pelo meu olhar e meu fazer. Entretanto, Jean Rouch reflete sobre o agenciamento da câmera tomando como referência a noção da câmera como órgão humano, extensão do ser que filma/fotografa, o "cine-olho" preconizado por Dziga Vertov ${ }^{10}$. A partir de seu trabalho em Os Mestres Loucos, Rouch desenvolveu o conceito de cine-transe. Ele situa o pesquisador com a câmera no mesmo plano dos filmados possuídos. Assim sendo, o ato de filmar é também da ordem da performance, em que todos são personagens: os que filmam e os que são filmados. Ou seja, é uma experiência de compartilhamento em que todos estão performatizando suas identidades de alguma forma. Para ele:

Conhecimento não é mais um segredo roubado para ser mais tarde consumido nos templos ocidentais de conhecimento. É resultado de uma busca interminável onde etnógrafos e etnografados se encontram num caminho que alguns de nós já chamam de "antropologia compartilhada"e (Rouch, 2003: 185 apud Gonçalves, 2008: epígrafe).

O fazer imagem das crianças, contando com a multiplicidade de improvisações de si suscitadas junto a mim e à câmera, remetia-me à noção de antropologia compartilhada. Apesar de não assumir propriamente a realização de uma antropologia compartilhada, inspiro-me no método que busca construir um conhecimento antropológico a partir de certa paridade epistemológica entre fotógrafos (geralmente pesquisadores ocidentais) e fotografados. A pesquisadora, para Rouch, é alguém que

\footnotetext{
${ }^{10}$ Dziga Vertov era documentarista russo dos anos 1920, autor do filme Um Homem com uma câmera, marco na história do cinema, conhecido por ser precursor do cinema-verdade. O termo tem como princípio o agenciamento da câmera. Ele associava o olho humano ao da câmera, aludindo à capacidade desta de apreender o real. Rouch desdobra a noção de cine-olho de Vertov e cria a de cine-transe, associando o fazer antropologia aos modelos de possessão dos interlocutores. Ver Gonçalves, 2009.
} 
participa, provoca, interage. Assim, o encontro etnográfico configura-se num etnodiálogo, em que as coisas são "etno-mostradas", "etno-pensadas", "etno-ditas". Trata-se da tentativa de vislumbrar a transformação pela qual passa o observador, que se modifica a partir do trabalho de "cine-etno-olhar" (Gonçalves, 2009). Na perspectiva do cine-transe, Rouch valoriza o encontro entre a pessoa que pesquisa e seus interlocutores na construção do conhecimento das ciências humanas, especialmente se a pesquisadora produz um material audiovisual. Nesse caso, a câmera é o objeto que estimula uma relação entre quem está atrás e quem está à frente dela. Em entrevista com Jean Paul Colleyn, Rouch (1995) reconhece a câmera como objeto catalisador capaz de suscitar e captar as mais sutil mudança na identidade em performance. Para o autor, manejar a câmera é uma forma de penetrar em um mundo em movimento junto a ela. "A câmera está dentro", é participante (Rouch, 1995: 70).

Do encontro com as crianças emergia, muitas vezes, uma construção performática desses sujeitos que unia subjetividade e objetividade, no sentido em que Gonçalves (2012) propõe em seus escritos sobre etnobiografia, subjetividade e etnografia. Como a câmera era um objeto que tem agência, mostrava coisas que o olho não vê. A sua fetichização confere a ela o estatuto de objeto que produz uma relação. A realidade apresentada fotograficamente, assim, é uma criação que surge a partir do encontro etnográfico. Não havia a realização de imagens da realidade dada a priori. Nos registros não existe uma coisa em si, mas imagens das coisas. O que surgiu na relação com as crianças é que a questão não tangenciava somente o modo como elas se apresentariam diante da câmera, mas também o modo como apresentavam o seu mundo com a câmera para mim. Nesse sentido, é compreendido que a fotografia apresenta-se como objeto ambíguo em que é possível ser denotativo e conotativo. Ela é, ao mesmo tempo, uma realidade construída com pessoas, equipamentos fotográficos, condições ambientes, impressão, etc., no sentido literal, em forma de papel ou arquivo virtual; e a expressão que identifica uma realidade construída, que conota aspectos implícitos a ela (Mitchell, 2002).

Em campo, atentei para outra possibilidade de construção de imagem. Muito além de definir o que ia ser evidenciado e como a imagem seria criada, estive a disposição do comando do outro na construção de sua imagem e ao agenciamento da câmera na performance desse outro; ao que o outro queria mostrar no encontro comigo com o equipamento. Aquele que estava sendo foco na fotografia era responsável 
também pela construção do que vai ser visto. Sua imagem era construída nesse encontro, não era algo dado. O choque da alteridade era potencializado com a câmera, e pareceu suscitar um ser que está em permanente formulação e que queria estar vinculado a determinado tipo de identidade e imagem de si. Havia noções próprias do que deveria ser mostrado e escondido da câmera. Percebi como as crianças queriam ver suas imagens, quais gestos deveriam se realçados, que objetos, em quais cenários, etc.

Quando eu passava por determinada casa de grade verde escura contorcida e porta recuada, frequentemente ouvia os gritinhos de duas meninas. Eram Bia e Estefane que me chamavam: "Tiiiiia, tiiiiiiiiiiiiiia!"11. Olhava para a escuridão funda da casa, e malmente enxergava a silhueta das meninas correndo em direção à porta. Quando alcançavam o clarão da rua, a menorzinha sorria, exibindo seu olhar de candura e seus dentes de leite dos recém quatro anos. Estefane, 6 anos, era mais ousada, e já dizia o que queria: "Tira uma foto minha?!". Colocava uma mão na cintura, arqueava a perninha esquerda aproximando um joelho do outro. Fazia pose. Construía sua performance no momento de encontro comigo e com a câmera.

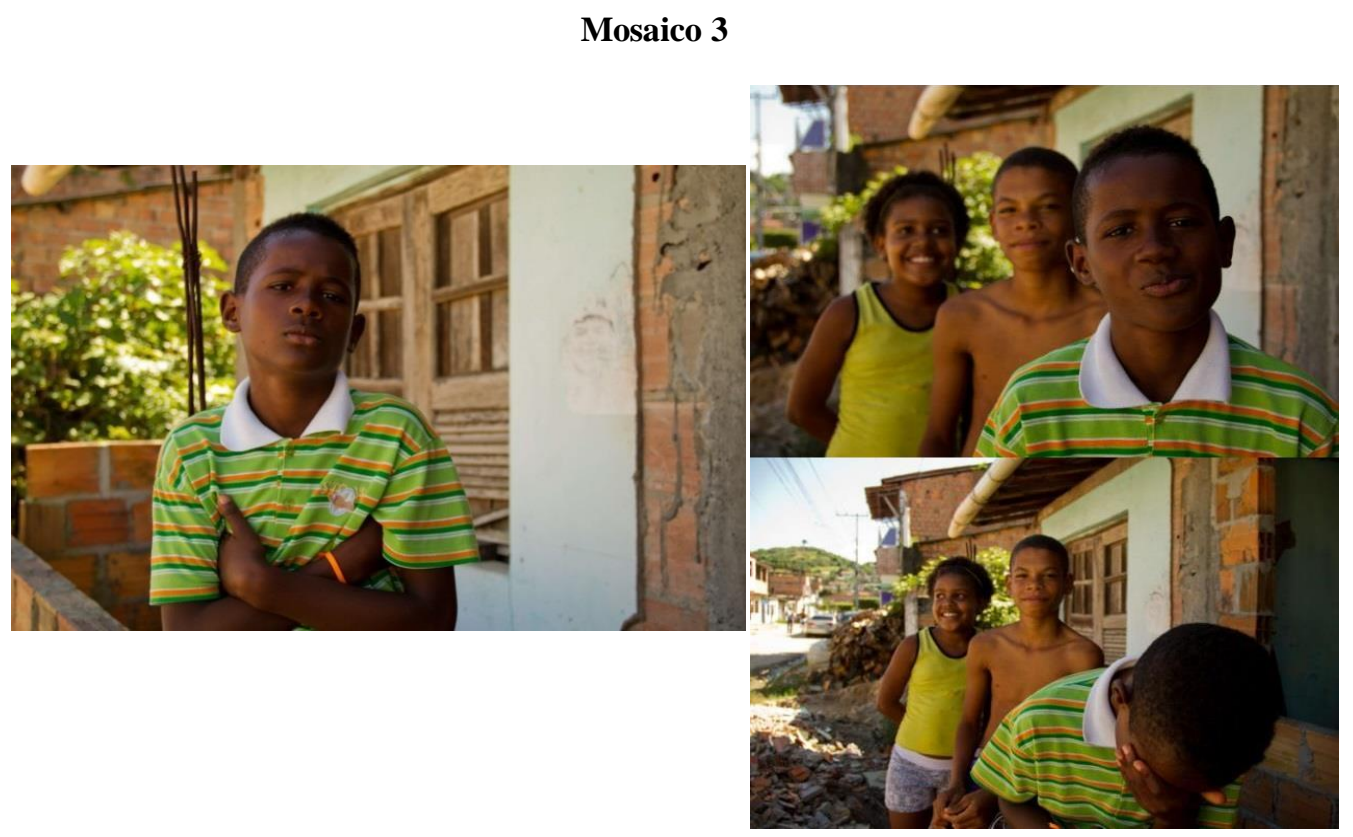

Mosaico 3: Na interação entre mim, as crianças e a câmera, a negociação de como a imagem seria construída ficou evidente na tentativa de Anderson em mostrar seriedade e não sustentar diante da relação.

\footnotetext{
${ }^{11}$ É muito comum em algumas regiões da Bahia o uso do termo para designar o adulto próximo, que faz parte do dia-a-dia da criança ou a quem ela deve deferência, somente por ser mais velho, e não tem necessariamente grau de parentesco consanguíneo.
} 
Um sorriso, uma piscadela de olho, um sinal das mãos e dos dedos, o esconder das mãos por debaixo dos braços, nas axilas, ou coladas na cintura, a inclinação da cabeça, cintura, pernas ou por inteiro, contrações na boca formando um beijo, ou uma expressão de desafio: tudo isso faz parte da composição da imagem, desse corpo que se constrói para a fotografia. Havia a tentativa e o exercício de certo controle sobre a sua própria imagem, por parte das crianças.

É preciso, entretanto, falar dos dispositivos performáticos e não simplificar o processo da construção de imagem. A minha interpelação como pesquisadora e, na época, moradora de Acupe, de certa forma, causava a ativação de uma performance nas crianças. A câmera possibilitou a apresentação de uma performance que diz respeito também à minha inserção no espaço, à conexão de minha presença à presença da câmera em campo, e à relação que mantive com as interlocutoras. Mesmo sem dirigir as crianças, as fotografias que fiz em Acupe indicavam qual a performance de si elas deveriam apresentar para mim naquele momento. A impressão de espontaneidade da performance diante da lente dependia de minha abordagem, do equipamento e de outros diversos fatores. Apesar de tentar retirar de mim o controle do processo de criar imagens, isso não significou necessariamente que controle foi dado inteiramente à criança. O que pode ser dito é que a imagem esteve sempre em negociação entre mim, o equipamento e as crianças. O percurso desencadeou uma distribuição no controle da feitura de imagens.

De gringa à tia, a minha identidade enquanto adulta pesquisadora com crianças foi alterada localmente. Corsaro (2005) em seu trabalho indica acontecer durante a pesquisa transformações e sedimentações no investigador. Além de gringa e tia, pude perceber que, à medida em que eu me aproximava mais das crianças, tentando não reger seus comportamentos, mas compartilhar suas práticas e brincadeiras, mais eu agia como uma "adulta não-típica" (Corsaro, 2003). Brinquei com elas, e ainda levei algumas palmadas quando engajada em seus jogos de competição e disputa.

O "adulto não-típico" é um termo designado por Corsaro para descrever a atitude de um adulto que não tenta transformar a interação com a criança em um processo de aprendizagem, não está preocupado em controlar e reger o comportamento ou ser a autoridade da relação. Algumas vezes tentei desfazer o papel de "tia", explicando às crianças que não era professora ou cuidadora delas. Em outras, o ideal do adulto atípico fracassou, posto que era demandada pelos adultos para "cuidar", ser a 
responsável da situação, acompanhar uma criança muito pequena de um lugar a outro, etc. Foi difícil o deslocamento da posição de adulta, e me desfazer da condição de sujeito responsável da relação.

Quando requisitada pelas crianças, eu abria mão de ser a pesquisadora que fotografava. Estimulei o interesse das crianças pelo equipamento fotográfico. Muitas vezes cedi o equipamento (câmera e gravador) às mãos das pequenas, entrando na brincadeira de deixá-las fotografar e usar o gravador como microfone. Isso foi mais recorrente com a câmera, e todas queriam se tornar as fotógrafas, entrar em ação atrás do visor óptico. Nem sempre isso era harmonioso, porque a vontade de brincar de fotografar era inesgotável, e a câmera passava de mão em mão ininterruptamente, por vezes gerando conflitos entre as crianças, manuseios inadequados e "dedadas" na lente. Apesar de assegurar que elas apertassem o botão certo e segurassem a câmera de modo estável, indicando onde era o zoom e onde não era indicado tocar, elas assumiam o controle do que queriam fotografar. A estratégia de dar a câmera às crianças não era central na pesquisa, mas apresentou-se de grande importância para o deslocamento da lógica adulta e para a negociação do meu lugar naquelas interações. Contribuiu para abertura à percepção do mundo na lógica da criança, condição necessária para a compreensão das práticas desses atores sociais, como proposto por Sarmento (2005).

\section{Mosaico 4}

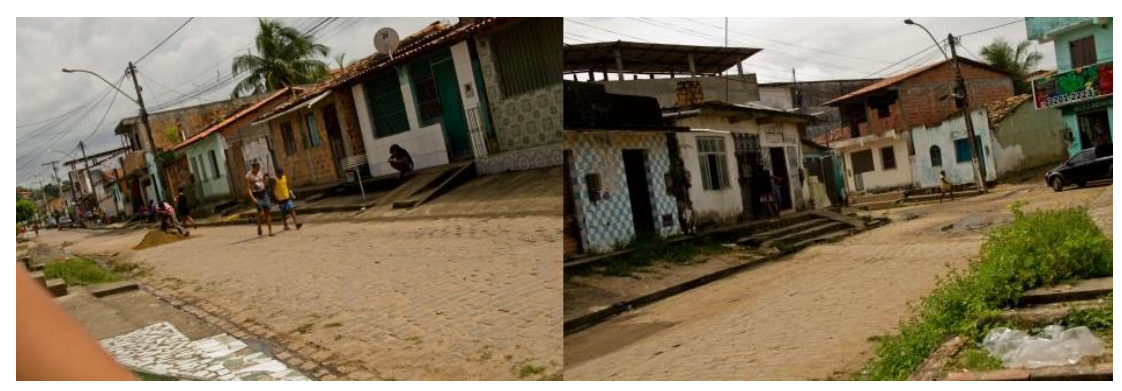

Mosaico 4: As crianças brincavam de disputar quem ficava mais tempo com a câmera na mão experimentando enquadramentos e numerosos cliques. Ficava mais tempo quem tinha maior número de coisas a fotografar. A rua em frente ao lar oferecia muitas opções.

Fotografias de Acupe tiradas por Estefane. 
Em primeira instância, o resultado evidenciou a alteração do ponto de vista, do olhar de quem fotografava. As imagens ficavam "tortas", algumas vezes pareciam não focar nada ou lugar algum. Elas criavam imagens frontais, de ângulo aberto, com planos panorâmicos e genéricos de partes da cidade em que estávamos: céu, ruas e casas. Havia a recorrência do enquadramento na altura dos olhos e em contra-plongée ${ }^{12}$, justamente por elas serem crianças de baixa estatura, ou ainda com foco doce ${ }^{13}$. Algumas fotografias ficaram com a iluminação estourada ${ }^{14}$, superexpostas à luz. Outras imagens revelavam curta distância focal de si ou dos sujeitos bem próximos a elas, em plano detalhe.

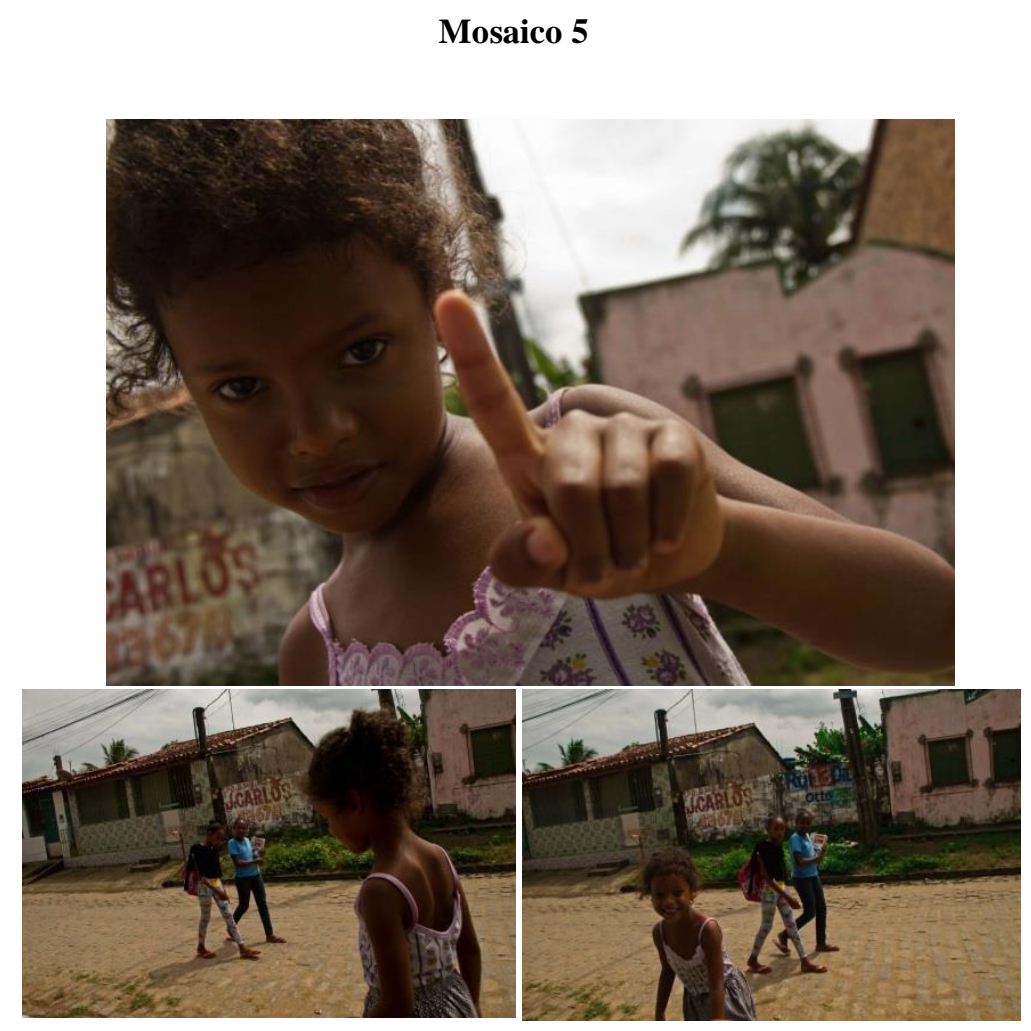

Mosaico 5: Mesmo sem domínio das técnicas de manuseio de uma câmera, as crianças interagiam com o equipamento como um velho conhecido brinquedo, num misto de curiosidade e intimidade.

Imagens capturadas por Eliseu.

\footnotetext{
${ }^{12}$ Contra-plongée, é uma palavra de origem francesa que significa "contra-mergulho". Ela define um enquadramento fotográfico que assume a câmera abaixo do nível dos olhos dos personagens, uma posição voltada para cima. A imagem situa a pessoa ou o objeto acima do espectador, engrandecendo o personagem e sugerindo a sua superioridade. Para conhecer melhor, acesse: https://www.agambiarra.com/plongee-e-contra-plongee-a-arte-de-medir-com-a-camera/

13 Trata-se de construção de imagens desfocadas.

${ }^{14}$ Desequilíbrio de luz em que há superexposição da fotografia à luz ambiente, suscitando efeito de alta temperatura e de distorção das cores de pessoas e objetos da cena registrada.
} 
Milton Guran (2000) diz ser eficaz a utilização da fotografia em pesquisa, quando os interlocutores se definem, principalmente, pela linguagem gestual. Para esse autor, a fotografia pode colaborar no relato antropológico em que as imagens tanto contribuem na reflexão sobre o que está sendo contado nas situações, quanto na construção da questão etnográfica. Neste artigo, explorei uma manifestação popular que acontece somente em determinado período do ano. O escopo etnográfico foi a performance como um todo, expressada pelos interlocutores que estão vivenciando frenética e continuamente uma dramatização. Eles estavam, geralmente, no estado de efervescência que o evento proporciona. Assim, fez-se plausível usar fotografias também para possibilitar "parar as coisas para que se veja o que só tinha sido entrevisto e imediatamente esquecido" (Guran, 2000: 159). Além disso, quando as crianças, cientes de minha pesquisa, me viam ou eram indagadas sobre o Nêgo Fugido, elas performatizavam.

Como todo campo proporciona adequação das questões etics, a experiência etnográfica de fotografar com crianças a partir das suas performances na manifestação de domingo se desdobrou em outras coisas. David Macdougall diria que "imagens corporais não são apenas imagens de nossos corpos, elas são também imagens do corpo atrás da câmera e de suas relações com o mundo" (2009: 63). Nessa relação com o mundo, vi meninas querendo fotografias bonitas, soltando os cabelos, olhando para a câmera e sorrindo, aproximando ou distanciando de outras para compor a imagem. Vi meninos sorridentes querendo construir uma imagem de seriedade e de respeito, mostrando seus dedos sinalizando legal, hang loose, ou paz e amor. Em outros momentos, os comportamentos também eram invertidos, e as meninas e os meninos acionavam posturas inversas: meninas fazendo pose de firmeza e confronto, e os meninos mostrando sorrisos, afetuosidades e companheirismo em grupo. Meninas expressavam feminilidade com elementos que correspondem a um perfil hegemônico de masculinidade e desafiam socialmente o papel da mulher na comunidade. Algo apontava para a dimensão da construção das identidades de gênero que perpassava, tanto o Nêgo Fugido, como a sociedade de Acupe como um todo. 


\section{Mosaico 6}

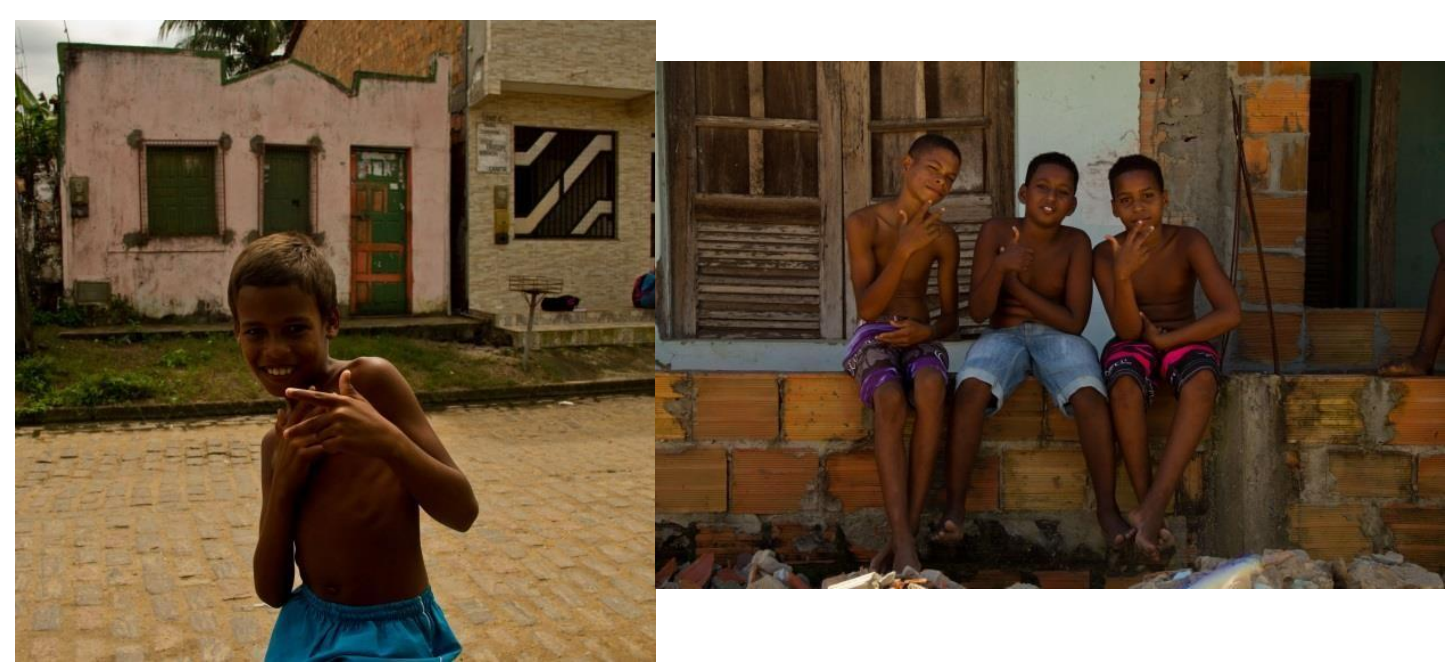

Ao refletir e buscar entender o que as crianças queriam dizer com suas imagens, identifiquei que expressavam dimensões de sua existência social, que não só mostravam somente algo de si, mas da comunidade como um todo. Mesmo reconhecendo a complexidade de tradução do que estava acontecendo, percebi aos poucos o quanto as imagens revelavam que as crianças estavam mostrando estar integradas em um grupo no qual fazem parte, ou no qual gostariam de participar, compartilhando elementos que acreditam caracterizá-las enquanto coletivo, seja geracional, racial, local e de gênero. Assim como havia indícios de que elas tinham singularidades que as destacavam do grupo, e que também era preciso mostrar para a câmera. Penso que a performance cotidiana e a performance das crianças no Nêgo Fugido são, de certo modo, da mesma natureza. Ou melhor, no Nêgo Fugido há uma intensificação momentânea de uma construção social vivida diariamente, em que crianças precisam acionar em si características que as qualifiquem como capazes de se adaptar, de exercer sua existência plena sem medo de opressões, de coragem, expressando resistência e abertura para confrontos, caso fosse necessário. Observei que as crianças expressavam a apropriação de um comportamento, e de todos os valores relacionados àquele modo de ser, em ambos momentos performáticos. Nesse contexto, arrisco dizer que não havia diferença na relação comigo durante o Nêgo Fugido e fora dele, no que diz respeito à performance que a câmera e minha presença suscitavam. Em certa medida, o comportamento que elas performatizavam para a câmera dizia que elas eram crianças autônomas, ativas, 
destemidas, fortalecidas, e que estavam preparadas para uma vida de adversidades. Elas intimidavam para que não fossem intimidadas, adotavam subjetivamente e de forma ressignificada, a atitude de quem as oprime. As crianças acionavam performaticamente determinadas imagens de si como estratégia de defesa construída por seu grupo racial para garantir a sobrevivência ao longo de séculos. Neste caso, o grupo é uma população negra que ainda luta na atualidade contra o racismo latente em uma sociedade erigida por relações raciais desiguais.

Estarem sendo fotografada fazia com que muitas crianças assumissem posturas, gestos e apresentações de si, incitando um de seus modos de atuar no mundo, e no Nêgo Fugido. Por isso, proponho que as crianças estivessem empenhadas em construir uma narrativa visual sobre si mesmas acionada também por mim e pela câmera. Há consonâncias no que foi proposto por Gonçalves (2012) ao considerar que pessoaspersonagens são frutos da relação entre sujeito pesquisado e antropóloga. $\mathrm{O}$ autor recusa a existência de binarismos entre pessoal e geral, indivíduo e cultura, explorando ao máximo a tensão entre racionalidade e subjetividade. Gonçalves, Marques e Cardoso (2012: 13) esclarecem que "a experiência do corpo em movimento na circulação opera como uma „escrita de siee - a criação de uma imagem de si negociada em ato”. Isso leva a pensar que a circulação do sujeito é a forma poética de uma "gestão de siee que expressa as possibilidades da "cultura". A performance criativa do sujeito vai além da clássica oposição entre agência individual e estrutura social (Gonçalves; Marques; Cardoso, 2012: 13 - 14).

Ao longo de minha estadia em Acupe, muitas pessoas solicitavam uma contradádiva: a devolução das fotografias. Depois de algum tempo, quando a minha presença parecia não mais despertar interesse no cenário acupense, as crianças, principalmente, passaram a pedir suas fotos. Elas queriam as imagens do Nêgo Fugido, da careta, do empinar arraia, e de outras brincadeiras do dia-a-dia em que as fotografei. Diante da demanda, resolvi escolher algumas fotografias para devolução. A maioria das fotos era de crianças que encenavam o Nêgo Fugido durante todos esses anos em que frequentei Acupe. Ou seja, eram fotos do ano de 2012 a 2015. Devolvi 25 imagens de crianças. Em alguns casos imprimi mais de uma foto da mesma pessoa, seja porque compartilhavam a cena com outras, ou porque algumas delas encenaram mais de um personagem ao longo dos domingos. Escolhi sob o meu parâmetro estético e a ingenuidade de que meu gosto contemplaria a preferência de quem foi fotografada. Dei preferência às fotos de crianças 
que mais observava durante a manifestação, aquelas com quem mais me relacionei no dia-a-dia. Orientei a escolha pela disponibilidade das pessoas em conversar comigo, a afinidade e consequente envolvimento que tinha com determinados interlocutores.

Em seguida, comecei a realizar entrevistas com as crianças durante a devolução das fotografias. Quando mediadas pelo pai ou responsável, acabavam por ser somente respostas dos adultos ou norteadas por eles, o que me fez relembrar do porquê de não querer fazer entrevistas no início da pesquisa de campo. As entrevistas não eram eficientes porque as crianças ficavam retraídas. A maioria delas se mantinha monossilábica diante do gravador e do nome "entrevista", dos pais e das perguntas; diferente dos encontros e conversas descompromissadas na rua, durante as brincadeiras ou com o intermédio da câmera. No cotidiano, as crianças assumiam outra postura, eram mais desenvoltas, mais autônomas e proativas no bate-papo, expressavam emoções mais genuinamente, aceitavam e rejeitavam temas com certa espontaneidade. Na entrevista, quando perguntava sobre o Nêgo Fugido, havia sínteses como "legal", "muito bom", etc. Vale pontuar que não me interessa aqui julgar o quão precisa é a narrativa das crianças em relação às narrativas oficiais ou dos adultos, mas gostaria de chamar a atenção mais uma vez para o fato de que as crianças respondiam às perguntas de outra forma: através do corpo, da dança, da língua para fora, do revirar dos olhos. No dia-adia, elas falavam do Nêgo Fugido cantando, brincando de ser Nêgo Fugido, simulando o transe e tremendo o corpo quando me viam. Aliás, em campo, eu me tornei um dispositivo interessante. Ver-me andando pelas ruas as instigava a dançar, cantar alto uma música da manifestação e chamar pelo Nêgo Fugido. Ao mesmo tempo em que, quando perguntadas diretamente, as crianças eram evasivas. As informações sobre o que elas pensavam sobre o que faziam não vinham através da verbalização, mas através da performance.

Todos os dias eu sentava, por algumas horas, numa esquina onde muitas crianças passavam os finais da tarde brincando. Todas vinham, em algum momento, falar comigo, convocar à brincadeira, perguntar coisas pessoais e mostrar suas proezas e peripécias. Certa feita havia dois integrantes da manifestação, Patrícia e Eliseu. Sabendo que eu estava interessada no Nêgo Fugido, Patrícia convocou as outras crianças para brincarem um modo subversivo da manifestação. As crianças ficaram pavorosas quando Patrícia, com seu corpinho de menina de oito anos e tranças no cabelo, começou a gritar com sua voz aguda e infantil uma música muito conhecida da manifestação. Todos 
começaram a correr, a se tremer, a se jogar no chão se debatendo, como se espasmos intensos e agudos subitamente acometessem os corpos, justamente como fazem os participantes durante a performance da agonia. Patrícia, tomada por um impulso repentino, subiu no portão que fechava o beco e, lá de cima, entoava o canto em alto volume repetidas vezes. Ela balançava o portão freneticamente, empurrando com braços e pernas a estrutura de metal corroído. Naquele dia, as crianças subverteram a manifestação enquanto brincavam. Fora do contexto dos domingos de julho, elas acionaram um estado corporal de frenesi intenso por alguns instantes para mostrar para mim o que era o Nêgo Fugido. Ou, no limite, o que elas entendiam que era a manifestação. Em minha frente, o saber das crianças era expressado fisicamente: na força e na flexibilidade dos movimentos, na intensidade e excessos de gritos, na superação dos limites e barreiras instituídas pelas estruturas, na efervescência grupal, na disposição para o que viesse e na potencial resistência física. O saber das crianças era corporalmente demonstrado em sua performatividade durante a brincadeira de Nêgo Fugido.

Ainda assim, nas entrevistas semi-estruturadas realizadas em 2015 com as 25 crianças, pude ouvir um pouco mais sobre o que elas pensavam sobre o cotidiano de Acupe, sobre a escola, sobre seus sonhos e medos, sobre as relações domésticas, e sobre as imagens devolvidas. Ao mostrar a fotografia, algumas crianças demonstraram alegria em se ver, e colocavam a imagem por cima de outras fotografias dependuradas na parede. Outras não. Octávio demonstrou muita insatisfação ao ver seu retrato. Ele preferia se ver fazendo contrações no rosto, com a língua para fora, mostrando a expressão performática do Nêgo Fugido, aquela que causa repulsa, desperta medo e desafia a audiência. Ele não foi o único a dizer isso. Quando devolvi a fotografia para Fabiano, ele também fez questão de demonstrar insatisfação. E revelou preferir uma foto com a língua para fora com o vermelho da anilina misturado à saliva, mostrando justamente o exagero estético e caricatural da performance. Ingenuamente entreguei uma fotografia em que Fabiano estava em movimento, uma cena da dança justamente porque muitas crianças indicavam gostar de dançar. Havia muitas imagens de Fabiano com a língua para fora, assim como fotografias da preparação, de momentos antes da pintura do rosto, momentos de fila antes da distribuição do figurino, ou sentados conversando com outras crianças. Somente na devolução da fotografia eu percebi que, 
no encontro, não estava conseguindo identificar a imagem que eles queriam construir, que imagem era importante para eles.

\section{Mosaico 7}
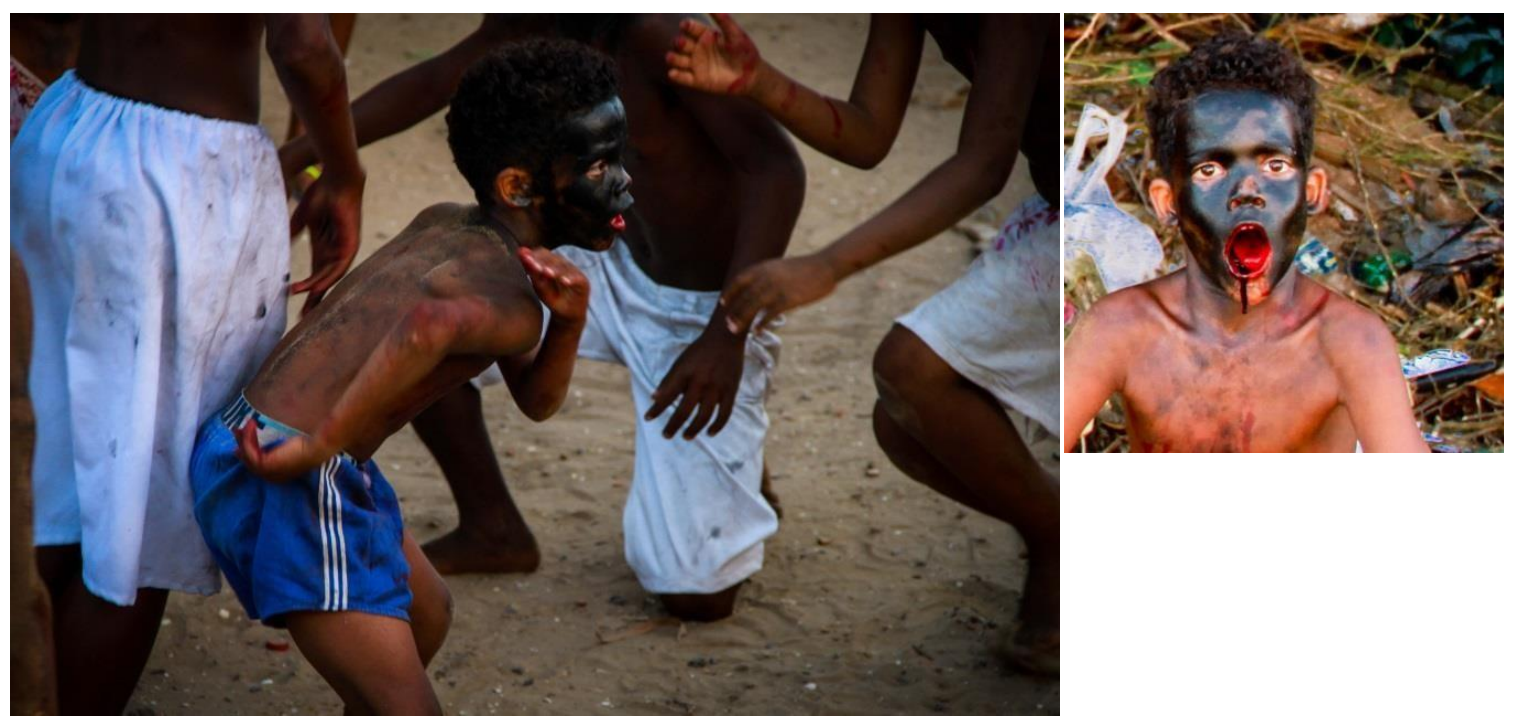

Mosaico 7: De um lado, a fotografia que Fabiano recebeu. Apesar disso, ele sempre performatizou a imagem que queria que a câmera registrasse.

Interpreto que o evento revela indícios acerca das imagens de si que as crianças do Nêgo Fugido querem apresentar. Ver-se mostrando a língua, contorcendo o rosto na construção da expressão grotesca que incita medo, demonstrar olhares desafiadores, gestos e posturas de confronto à audiência pode ser, de certa forma, uma maneira de identificar em si uma personalidade que condiz com a manifestação e que também o constitui socialmente. Diz também de um modo de ser com o qual essas crianças querem estar relacionadas, e como elas querem ser vistas pelos outros. É dizer algo sobre suas identidades e personalidades em performance. As crianças pareciam indicar que elas queriam estar relacionadas às qualidades que valorizam, como braveza, coragem, seriedade, dignidade e respeito, mesmo que seja através do medo e da repulsa que o grotesco pode provocar. Apresentar certa autoridade fantástica a quem a audiência deveria certa deferência, e de quem é preciso se defender. Elas indicam corporalmente a apropriação do comportamento alegórico estereotipado que expressa tais valores e modos de ação. Indicam ao observador que gostariam de se ver retratadas com o que há de melhor na performance do Nêgo Fugido: as expressões corporais que compõem e 
potencializam, no imaginário, o espirito de luta contra a colonização, o protagonismo negro no confronto histórico contra o poder hegemônico e supremacia branca, da força e da resistência da cultura afro-brasileira, a não resignação ou aceitação do status quo e da ordem racista atual. A expressão do grotesco, do exagero, do desafio, de excesso de sofrimento, de luta e de superação, pode ter o intuito de maximizar tais sentimentos na identidade dos participantes, expressando um momento de intensificação de valores da comunidade, de aspectos que os qualificam e os identificam, necessários para sua existência cultural e social.

Inicialmente houve tentativas de realizar fotografias que tomassem a questão etnográfica "Como as crianças constroem a si mesmas através do Nêgo Fugido" como foco principal de modo ainda mais criativo. Cogitei fazer fotografias que não evidenciassem o rosto delas, que não expusessem suas identidades. Recorri a outros ensaios fotoetnográficos que lidam com questões éticas relacionadas aos registros fotográficos de crianças e adolescentes. Houve momentos em que fotografei influenciada pelo trabalho de Cristina Pedroza cujo ensaio Em nome do sagrado revela práticas e assistências religiosas entre adolescentes de unidades socioeducativos de cidades do Brasil. Nas imagens feitas pela antropóloga, não vemos o rosto dos personagens sociais, nem mesmo dos líderes religiosos. Experimentei isso no campo. Realizei fotos contra luz, ou em plano detalhe para compor imagens que não mostrassem o rosto das crianças. Algumas vezes alcançava resultados satisfatórios, outras não. O experimento, grosso modo, desencadeou um desconforto e gerou algumas questões sobre a estratégia. Por que eu esconderia o rosto dessas crianças? Elas não eram menores infratores, não são crianças em situação de abandono, não estão exercendo práticas ilegais ou que desqualifiquem sua imagem. 


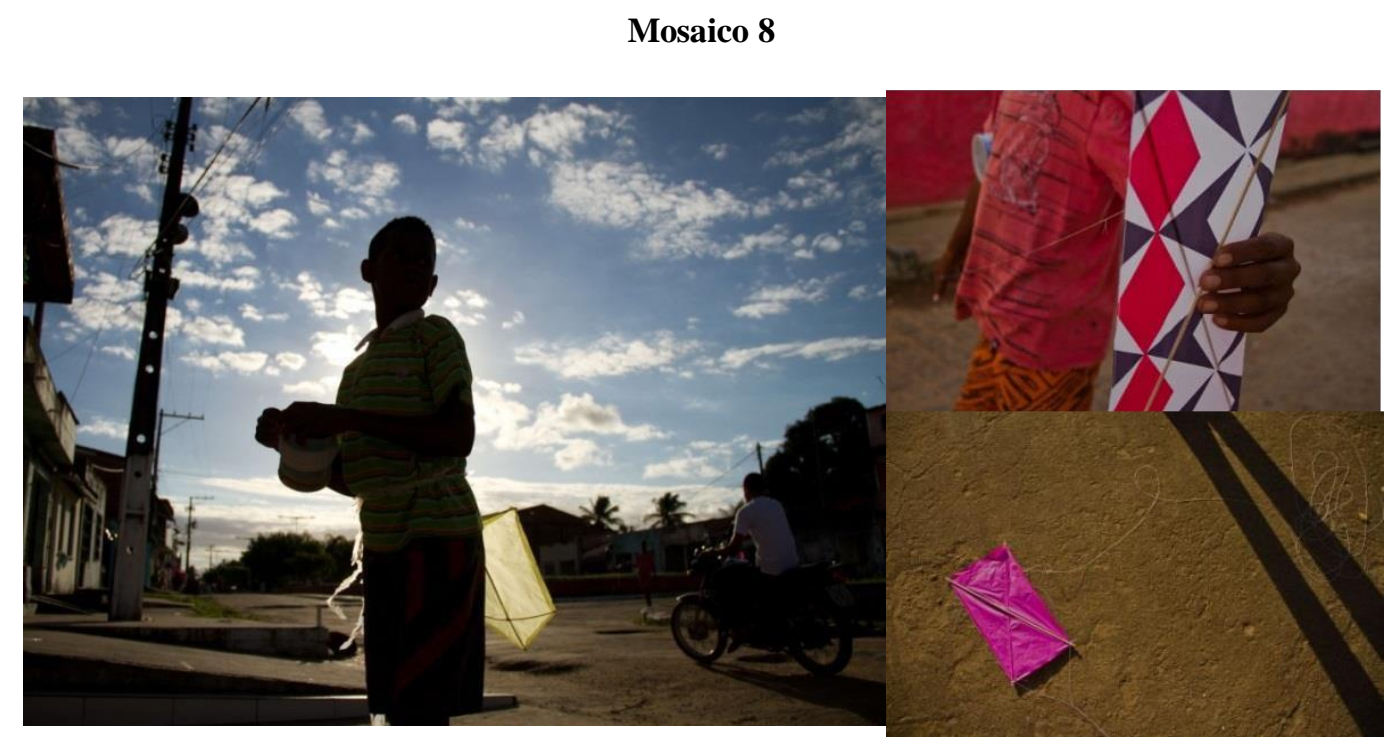

Mosaico 8: Usar estratégias como contra luz e planos detalhes, de modo contextualizado, era uma tentativa de dar conta de escolhas estéticas que dialogavam com a relação particular que estabeleci diariamente com as crianças, principalmente os meninos, durante a brincadeira de pipa. Liberdade, apropriação do espaço, empoderamento na brincadeira, informações minuciosas sobre a prática de empinar pipa, eram coisas que eu percebia em campo. Descontextualizadas, entretanto, as fotografias expressam um anonimato que não condiz com o lugar ocupado por essas crianças em Acupe.

Apresentar a manifestação da cultura negra popular baiana, o Nêgo Fugido, de forma digna sempre foi condição para a realização do trabalho. A proposta era reconhecer a importância compreendo as suas práticas culturais em Acupe ${ }^{15}{ }^{15}$ Logo, esconder o rosto deixou de ser um método para, de vez em quando, aparecer como um recurso e experimentação estética. A pesquisa contou com a fotografia para mostrar, não para esconder. Reconheço, porém, que mostrar rostos em imagens não é sinônimo de dignificar. Contar com a colaboração das crianças e respeitar a agência dessas interlocutoras na elaboração de fotografias que as apresentasse, entretanto, mostrou-se como uma tentativa ética de diálogo e produção fotoetnográfica.

Um objetivo basilar foi também refletir sobre produzir imagens e textos compatíveis com a versão que o grupo gostaria de apresentar, de se ver representado. Nesse sentido, existe uma relação entre o processo de fazer as imagens e o mostrar o rosto como resultado desse percurso que tenta dar conta do que as interlocutoras querem ver sobre si mesmas. Assim, mostrar o rosto é revelar as pessoas-personagens que frequentemente são destituídas de autonomia sobre a sua própria imagem, como é o

\footnotetext{
${ }^{15}$ Com isso, não quero dizer que o Nêgo Fugido não se valha em si mesmo. Seria um discurso muito paternalista e colonizador, muito distante de meus propósitos.
} 
caso das crianças, e como tem sido historicamente com a comunidade negra. É tentar dizer o inverso. As crianças são protagonistas no cotidiano em que vivem e têm certa agência sobre o que apresentam e querem mostrar sobre si.

Numa palestra sobre negritude e auto-afirmação identitária negra que aconteceu no Centro de Estudos Afro-Orientais da Universidade Federal da Bahia (CEAO/UFBA) há muitos anos atrás, a socióloga Vilma Reis falou da importância dos afrodescendentes acionarem seus nomes e sobrenomes nas apresentações de si. A estratégia colaboraria com a luta contra o círculo vicioso do racismo e da discriminação, que conta com o desfacelamento da identidade negra, a destituição de sua história e de seus vínculos culturais. Logo, mostrar o rosto é revelar os donos da história de vida que está sendo contada, é não destituir os atores de sua experiência, de sua história. Mostrar o rosto é empoderar, é identificar os sujeitos no que diz respeito a como eles vivem, local onde eles vivem e as ancestralidades que vivenciam, mostrando não só suas identidades, mas também suas influências culturais e atual modo de vida.

\section{Considerações Finais}

Por fim, reflito que o campo mostrou que a performance das crianças no Nêgo Fugido faz parte de um aprendizado acionado pelo corpo inteiro para a manutenção da tradição. Não há mera imitação, mas uma expressão cênica de uma história através da manifestação, constituindo-se como um saber corporificado sobre si e sobre o coletivo que performatizado à medida que é reconstruído.

Na maior parte do tempo, as crianças estão constituindo suas realidades e afetos, protagonistas no cotidiano e da imagem de si que construíam performaticamente junto a mim e a câmera, apreendendo o mundo de corpo inteiro de um modo particular. É possível dizer que, no encontro, as crianças também constituíam suas imagens do Nêgo Fugido. Tais impressões só foram possíveis de serem construídas dentro da relação entre nós. Assim, propus problematizar a performance e a imagem desses interlocutores no contexto com a câmera, demonstrando que essa etnografia nasce da relação estabelecida entre as parte humanas e não-humanas: e tudo isso cria uma realidade própria a nós. Esse processo possibilitou acesso ao imaginário das crianças, às informações acerca da subjetividade de sujeitos expressa através das suas identidades em performance. Partindo desse pensamento, finalizo o artigo fazendo das palavras de 
Sztutmam as minhas: “o visual não é mera metáfora, ele é condição que subjaz à produção de conhecimento" (2009: 125).

\section{Referências}

CLIFFORD, James. A experiência etnográfica: antropologia e literatura no século XX. Rio de Janeiro: Editora UFRJ, 2008.

EYERMAN, Ron. The Past in the Present: Culture and the Transmission of Memory. Acta Sociologica, Vol. 47, n 2, p. 159-169, 2004.

GURAN, Milton. Fotografar para descobrir, fotografar para contar. Cadernos de Antropologia e Imagem, Rio de Janeiro, v. 10, n. 1, p. 155 - 165, 2000.

INGOLD, Tim. Pare, olhe, escute! Visão, audição e movimento humano. Ponto Urbe 3, 2008.

LATOUR, Bruno. Aramis, or the love of technology. Cambridge (EUA); Londres (Inglaterra): Harvard University Press, 1996.

LAVE, Jean. Situating learning in Communities of practice. In: RESNICK, Lauren B.; LEVINE, John M.; TEASLEY, Stephanie D. Perspectives on socially shared cognition. Washington (EUA): American Psychological Association, 1991. P. 63-82. Disponível em: < www.seachangecop.org/.../1991\%20Jean\%20Lave\%...>. Acesso em 24 fev. 2016.

Learning as Participation in Communities of Practice. Annual Meeting of the

American Educational Research Association. San Francisco, 1992. Disponível em <http://www.udel.edu/educ/whitson/897s05/files/Lave92.htm>. Acesso em 24 fev.

2016.

MITCHELL, W. J. T. O ensaio fotográfico: quatro estudos de caso. Cadernos de Antropologia e Imagem, Rio de Janeiro, vol. 15, n. 2, p 101- 131, 2002.

PEDROZA, Kita. Em Nome do Sagrado: ensaio fotográfico. Rio de Janeiro: Centro Cultural Justiça Federal, 2011.

PINTO, Monilson dos Santos. Nego fugido: o teatro das aparições. 2014. 164 f. Dissertação (mestrado) - Universidade Estadual Paulista "Julio de Mesquita Filho", Instituto de Artes.

RAMOS, Ana Maria de Aragão. Nego Fugido - Representação da Liberdade Escrava no Recôncavo Baiano. Dissertação de Mestrado em História Social. Pontifícia Universidade Católica de São Paulo. 1996.

ROUCH, Jean. 54 anos sem tripé. Entrevista a Jean Paul Colleyn. Cadernos de Antropologia e Imagem, v. 1, n. 1, p. 65-74, 1995.

SARMENTO, Manuel Jacinto. Gerações e Alteridade: Interrogações a partir da sociologia da infância. Educ. Soc., Campinas, v. 26, n. 91, p. 361-378, Maio/Ago 2005. Disponível em <http://www.cedes.unicamp.br>. Acesso em 22 nov. 2015. SCHECHNER, Richard. O que é performance? Performance studies: introduccion. Second Edition. New York \& London: Routledge, 2006. P. 28-51.

Pontos de contato entre o pensamento antropológico e teatral. Cadernos de Campo, São Paulo, n. 20, p. 1-360, 2011.

. "Pontos de Contatos" Reinventados. In: DAWSEY, John C. MULLER, Regina

P. HIKIJI, Rose Satiko G. MONTEIRO, Marianna F. M. (Orgs.). Antropologia e Performance. Ensaios NaPedra. São Paulo: Terceiro Nome, 2013. Série Antropologia Hoje.

SZTUTMAN, Renato. A utopia reversa de Jean Rouch: de Os mestres loucos a Petit à Petit. Devires, Belo Horizonte, v. 6, n. 1, p. 108 - 125, Jan/Jun 2009.

TAUSSIG, Michael. Mimesis and Alterity. A Particular History of the Senses. London/ New York: Routledge, 1993.

Recebido em: 30/05/2017. Aprovado em: 05/07/2017. 